\title{
Extragonadal yolk sac tumor (endodermal sinus tumor) presenting with biliary tract obstruction in a woman
}

\author{
Alicia Topoll ${ }^{1}$, Lalan Wilfong ${ }^{1,2}$, Dale O'DelI $^{1}$, Mark Feldman ${ }^{1}$ \\ 1. Texas Health Presbyterian Hospital of Dallas, Dallas, Texas, USA. 2. Texas Oncology, Dallas, Texas, USA
}

Correspondence: Mark Feldman. Address: Internal Medicine Department, 8200 Walnut Hill Lane, Dallas, Texas 75231 , USA. E-mail: DrMarkFeldman@texashealth.org

Received: May 28, 2015

DOI : $10.5430 /$ crim.v2n3p44
Accepted: June 22, 2015

URL: http://dx.doi.org/10.5430/crim.v2n3p44

\section{Abstract}

A 35-year-old woman presented to her primary care physician with early satiety, weight loss, nausea, vomiting, and pruritus. She was eventually found to have a pancreatic mass obstructing the bile duct. The mass was evaluated by endoscopic retrograde cholangiopancreatography (ERCP) and endoscopic ultrasonography (EUS) with biopsy. Histopathology results revealed a high grade malignant neoplasm of uncertain type. The tumor was further characterized by open biopsy, which revealed a yolk sac tumor (endodermal sinus tumor). Her disease was unresectable. Serum alpha-fetoprotein (AFP) levels were markedly elevated $(693.3 \mathrm{ng} / \mathrm{ml}$; reference range: $0-8 \mathrm{ng} / \mathrm{ml})$. The patient was treated with bleomycin, etoposide, and cisplatin (BEP) with a partial response and a persistently elevated serum AFP of $139.7 \mathrm{ng} / \mathrm{ml}$. She then received salvage chemotherapy with paclitaxel, ifosfamide, and cisplatin (TIP), with a minimal response (serum AFP, $68 \mathrm{ng} / \mathrm{ml}$ ). She next received an autologous bone marrow transplant, with a decline in AFP to $19 \mathrm{ng} / \mathrm{ml}$ after the first of two tandem transplants. This case report illustrates a rare presentation of an extragonadal endodermal sinus tumor in a woman with biliary tract obstruction as the predominant manifestation.

\section{Keywords}

Extragonadal germ cell tumor, Yolk sac tumor, Endodermal sinus tumor, Biliary obstruction

\section{I ntroduction}

Extragonadal nonseminomatous malignant germ cell tumors are rare and include choriocarcinomas, embryonal carcinomas, endodermal sinus tumors (yolk sac tumors), malignant teratomas, and mixed germ cell tumors. In women, endodermal sinus tumors are extremely rare ${ }^{[1]}$. These tumors typically occur in men between the ages of 20-30 years ${ }^{[2]}$ and arise in the testes (gonadal) or along the urogenital ridge (extragonadal). Extragonadal endodermal sinus tumors may cause symptoms including chest pain, cough, shortness of breath, fever, weight loss, night sweats or the superior vena cava syndrome ${ }^{[1,3-5]}$. We present a unique case of a 35 -year-old female with an endodermal sinus tumor adjacent to the pancreas presenting with biliary tract obstruction. 


\section{Case report}

A 35-year-old previously healthy woman developed early satiety, a 30 pound weight loss, nausea, vomiting, and generalized pruritus. She was evaluated by her primary care physician and found to have an elevated total serum bilirubin level of $2.5 \mathrm{mg} / \mathrm{dl}$, alkaline phosphatase of $526 \mathrm{U} / \mathrm{L}$, AST $147 \mathrm{U} / \mathrm{L}$, and ALT $291 \mathrm{U} / \mathrm{L}$ (see Table 1).

Table 1. Patient Laboratory Findings *

\begin{tabular}{lllllll}
\hline Serum Analyte & June 9, 2014 & June 13, 2014 & June 20, 2014 & $\begin{array}{l}\text { Reference Range } \\
\text { (Outside Laboratory) }\end{array}$ & August 1, 2014 & $\begin{array}{l}\text { Reference } \\
\text { Range }\end{array}$ \\
\hline $\begin{array}{l}\text { Bilirubin, Total } \\
\text { (mg/dl) }\end{array}$ & 2.5 & 4.8 & 9.4 & $0.0-1.5$ & 1.4 & $0.2-1.2$ \\
$\begin{array}{l}\text { Alkaline } \\
\text { Phosphatase }\end{array}$ & 526 & 468 & 625 & $10-130$ & 101 & $0-98$ \\
$\begin{array}{l}\text { (U/L) } \\
\text { AST (U/L) }\end{array}$ & 147 & 215 & 198 & $5-34$ & & \\
$\begin{array}{l}\text { ALT (U/L) } \\
\text { LD (U/L) }\end{array}$ & 291 & 346 & 257 & $5-41$ & 28 & $<30$ \\
$\begin{array}{l}\text { AFP (ng/ml) } \\
\text { beta HCG (IU/L) }\end{array}$ & & & & & 30 & $1-34$ \\
\hline
\end{tabular}

* The following studies were nonreactive or negative on 6/13/2014 or 6/20/2014: hepatitis A virus IgM, hepatitis B virus core IgM, hepatitis B surface antigen, hepatitis $\mathrm{C}$ antibody, serum ferritin, antinuclear antibodies, Epstein Barr virus antibody and Monotest.

Abdominal ultrasonography showed a contracted gallbladder and a bile duct diameter of $2 \mathrm{~mm}$ with no intrahepatic biliary dilatation. She was referred to a gastroenterologist who recommended a liver biopsy. Three weeks later, she was scheduled for a sonography-guided percutaneous liver biopsy. However, the pre-biopsy ultrasonographic images now revealed a nearly $4 \mathrm{~cm}$ pancreatic mass (see Figure 1A); this mass had not been present on the earlier study. Liver biopsy was therefore deferred. CT scan revealed dilated intrahepatic bile ducts, two distinct masses adjacent to the head of the pancreas (see Figure 1B), and lymphadenopathy in the porta hepatis area. She underwent ERCP with biliary stenting and EUS-guided biopsy of the mass. Initial biopsy results showed a poorly differentiated carcinoma (non-small cell, non-squamous cell). She was subsequently admitted for port placement and laparoscopic biopsy of the mass for further histopathological characterization of the tumor.
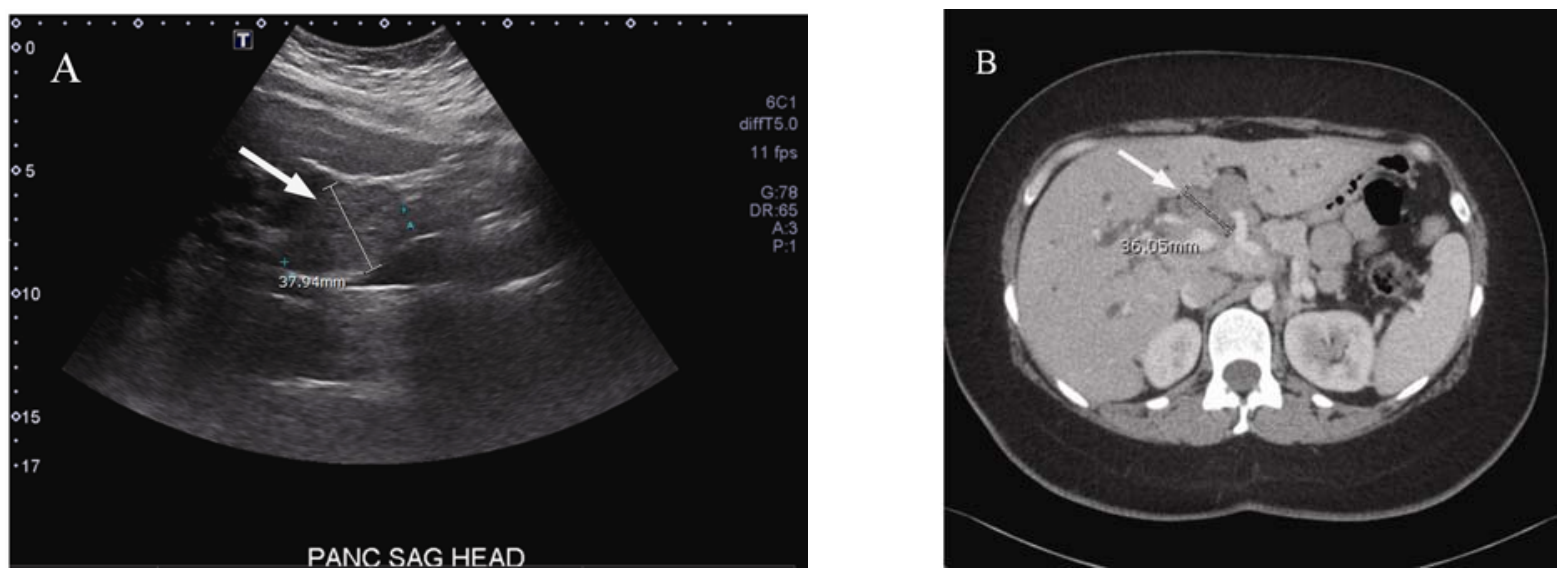

Figure 1. Tumor imaging. A: Ultrasonography of pancreatic mass (arrow); B: CT showing mass adjacent to the pancreas (arrow). The mass was nearly $4 \mathrm{~cm}$ in diameter

Physical examination revealed a well-developed female. Blood pressure was 116/60 $\mathrm{mmHg}$, pulse was regular at 62 beats per minute, temperature was $97.8^{\circ} \mathrm{F}$, and oxygen saturation was $100 \%$ on room air. Her cardiovascular, pulmonary, and musculoskeletal exams were normal. Abdominal examination was significant for only mild epigastric tenderness without 
hepatosplenomegaly. No masses were palpable. At the time of hospital admission on August 1, 2014, laboratory exam revealed a white blood count of 5,150 per $\mathrm{mm}^{3}$ and a hemoglobin level of $10.9 \mathrm{~g} / \mathrm{dl}$. The total serum bilirubin level was now $1.4 \mathrm{mg} / \mathrm{dl}$, and the serum alkaline phosphatase, AST, and ALT levels were 101, 28, and $30 \mathrm{U} / \mathrm{L}$, respectively (see Table 1). Renal function was normal. Her disease was unresectable due to significant portal vein involvement. Laparoscopic biopsy of the tumor showed a neoplasm that was immunoreactive to cytokeratin, alpha fetoprotein (AFP), glypican-3, and SALL4 (see Figure 2), diagnostic of an endodermal sinus tumor. After the biopsy result was obtained, a serum AFP was found to be elevated at $693.3 \mathrm{ng} / \mathrm{ml}$ (reference range: $0-8 \mathrm{ng} / \mathrm{ml}$ ): the serum $\beta$-HCG level was undetectable $(<1 \mathrm{IU} / \mathrm{L})$.
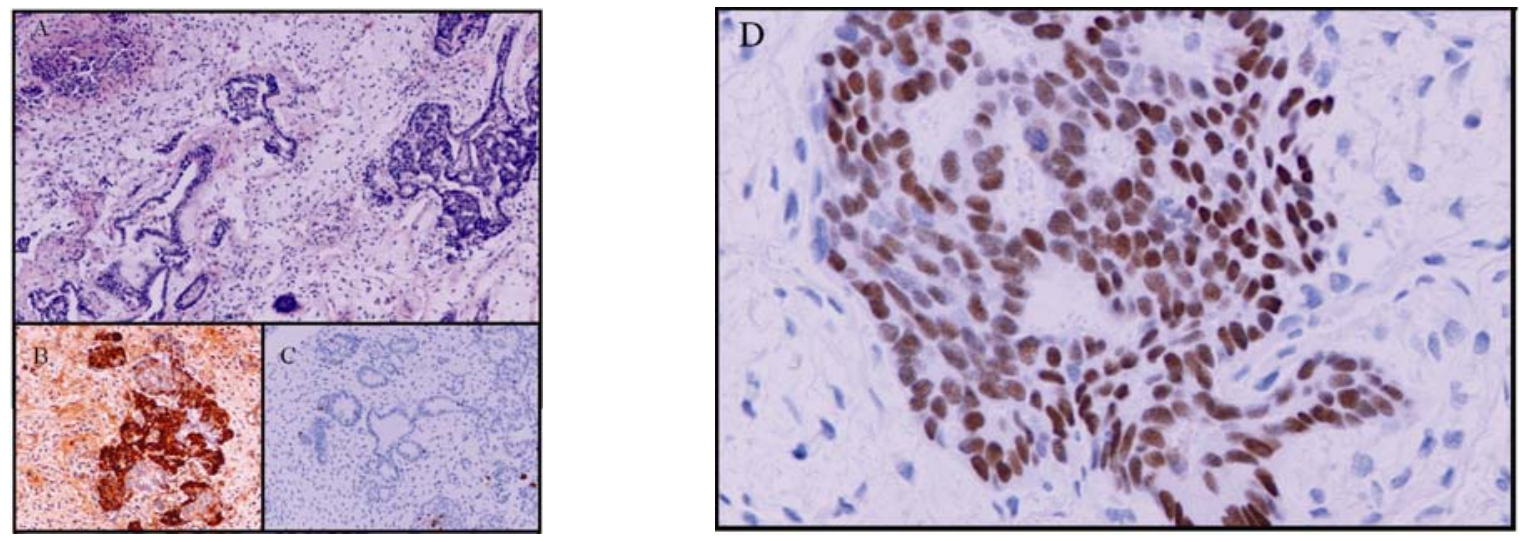

Figure 2. Tumor histopathology. A: Hematoxylin and eosin stain. High power view demonstrating formed glands and tubules with a myxoid stroma; B: Positive alpha fetoprotein immunostain; C: Negative Oct 3/4 immunostain; D: Positive SALL4 immunostain

She was treated with four cycles of bleomycin, etoposide, and cisplatin (BEP) with a partial response. However, tumor progression was seen on follow up imaging, in addition to a persistently increased serum AFP level of $139.7 \mathrm{ng} / \mathrm{ml}$. She was then given salvage chemotherapy with paclitaxel, ifosfamide and cisplatin (TIP), with a suboptimal response (AFP, $68 \mathrm{ng} / \mathrm{ml}$ ).

Given that she still had active disease with no further treatment options, she is currently undergoing tandem (2-step) autologous bone marrow transplantation and has already experienced a decrease in her serum AFP to $19 \mathrm{ng} / \mathrm{ml}$ after the first of two planned autologous stem cell transplants. The conditioning regimen used on both steps was G-CSF in combination with cyclophosphamide (G-Cy). The chemotherapy agents used on both steps were high dose cisplatin and etoposide.

\section{Discussion}

Our patient presented with signs of biliary tract obstruction from an extragonadal germ cell tumor located in the pancreatic head region, which has not previously been reported in endodermal sinus tumors. We are aware of only 3 cases of gonadal or extragonadal germ cell tumors involving the pancreas. In 2004, L. Wang et al. reported a 54-year-old man with a mixed testicular germ cell tumor (a seminoma with focal teratoma) with pancreatic metastases resembling a choriocarcinoma as the main clinical manifestation of his disease ${ }^{[6]}$. In 2010, Schmidt reported a 74-year-old man with obstructive jaundice due to an extragonadal embryonal cell carcinoma with periportal lymph node involvement; serum AFP and beta HCG were normal ${ }^{[7]}$. Finally, in 2013, J. Wang et al. reported a 12-month-old girl with a mixed extragonadal germ cell tumor (endodermal sinus tumor plus teratoma) arising in the head of the pancreas and causing obstructive jaundice and associated with a markedly elevated serum AFP level $>2,000 \mathrm{ng} / \mathrm{ml}^{[8]}$. Ours is the first case report of a woman presenting with biliary obstruction as the initial sign of an endodermal sinus tumor. 
Extragonadal germ cell tumors typically originate along the midline. Presenting symptoms may include chest pain, cough, and shortness of breath in thoracic disease and abdominal pain, weight loss and fever in abdominal disease. Endodermal sinus tumors are a very rare type of nonseminomatous germ cell tumor, particularly in women ${ }^{[9]}$. They typically occur in males between the ages of 20-30 years ${ }^{[2]}$. Germ cell tumors much more commonly arise in gonadal tissues (ovaries or testes) while extragonadal germ cell tumors are hypothesized to originate from germ cells that do not undergo normal migration along the urogenital ridge or that undergo reverse migration ${ }^{[2,5,10]}$. The most common site for extragonadal germ cell tumors is the anterior mediastinum, which can cause cough, chest pain, shortness of breath, fever, and weight loss ${ }^{[1-5]}$. When the initial presentation appears to be extragonadal, evaluation must exclude a primary gonadal carcinoma in situ since extragonadal metastases are common at time of presentation ${ }^{[2,6,11]}$. Primary gonadal tumors have been reported to undergo necrosis or "burn out", with resultant presenting symptoms being extragonadal metastasis ${ }^{[2,3,6]}$. Due to this concern, it is sometimes recommended that the affected patient undergo prophylactic oophorectomy or orchiectomy.

There is an increased risk of a variety of hematologic disorders in patients with extragonadal germ cell tumors including acute myelogenous leukemia, myelodysplasia, systemic mastocytosis, and histiocytosis X (Langerhans cell histiocytosis) ${ }^{[12,13]}$. These conditions may present synchronously or within the first 6 months after diagnosis of the extragonadal germ cell tumor. They are associated with isochromosome $12 \mathrm{p}^{[5]}$. Endodermal sinus tumors contain AFP and, when more than one cell line is present (mixed tumors), the tumor may also produce $\beta-\mathrm{HCG}^{[9,11]}$ (see Table 2). On microscopy, the tumors often have Schiller-Duval bodies, a glomerulus-like blood vessel surrounded by tumor cells. The tumor may demonstrate a microcystic or reticular pattern ${ }^{[14]}$.

Table 2. Extragonadal Germ Cell Tumor Markers ${ }^{[14-17,19]}$

\begin{tabular}{|c|c|c|c|c|c|c|c|c|c|c|c|}
\hline & $\begin{array}{l}\text { Serum } \\
\text { AFP }\end{array}$ & $\begin{array}{l}\text { Serum } \\
\beta \text {-HCG }\end{array}$ & $\begin{array}{l}\text { Tumor } \\
\text { PLAP }\end{array}$ & $\begin{array}{l}\text { Tumor } \\
\text { Gypican-3 }\end{array}$ & Tumor CD30 & $\begin{array}{l}\text { Tumor } \\
\text { SALL4 }\end{array}$ & $\begin{array}{l}\text { Tumor } \\
\text { Oct } 3 / 4\end{array}$ & $\begin{array}{l}\text { Tumor } \\
\text { NANOG }\end{array}$ & $\begin{array}{l}\text { Tumor } \\
\text { SOX2 }\end{array}$ & $\begin{array}{l}\text { Tumor } \\
\text { UTF1 }\end{array}$ & $\begin{array}{l}\text { Tumor } \\
\text { TCL1 }\end{array}$ \\
\hline Seminoma & - & - & + & - & - & + & + & + & + & + & + \\
\hline $\begin{array}{l}\text { Yolk Sac } \\
\text { Tumor }\end{array}$ & + & - & $+/-$ & + & - & + & - & - & - & - & - \\
\hline $\begin{array}{l}\text { Embryonal } \\
\text { Carcinoma }\end{array}$ & + & - & $+/-$ & - & + & + & + & $+/-$ & + & + & - \\
\hline $\begin{array}{l}\text { Pure } \\
\text { Teratoma }\end{array}$ & + & - & - & - & - & $+/-$ & - & - & + & - & - \\
\hline $\begin{array}{l}\text { Chorio- } \\
\text { carcinomas }\end{array}$ & - & + & - & - & - & - & - & - & - & - & - \\
\hline
\end{tabular}

Nonseminomatous germ cell tumors are typically very sensitive to chemotherapy agents, and thus radiation therapy is not typically recommended as first line therapy. Endodermal sinus tumors are especially sensitive to cisplatin-based chemotherapy regimens ${ }^{[2,4,7,8,15,16]}$. Typical treatment regimens include bleomycin, etoposide, and cisplatin (BEP) for four cycles. Baseline pulmonary function tests must be obtained before using bleomycin and, if bleomycin is contraindicated due to underlying lung disease, alternate treatment regimens may include ifosfamide in place of bleomycin, with or without stem cell transplant ${ }^{[4,12,17]}$. Patients such as our patient who are resistant to initial BEP therapy have a worse prognosis ${ }^{[18]}$. Debulking surgery is not initially recommended ${ }^{[15,18]}$, but if repeat serum tumor markers, such as AFP, remain elevated or increase with residual bulky disease on imaging studies, surgical resection, if the tumor is deemed resectable, and two additional cycles of chemotherapy are recommended ${ }^{[19]}$.

The utility of autologous stem cell transplantation is not well-established for chemotherapy-resistant disease. However, her disease seems to be responding to this therapy so far, although the response has not been brisk.

\section{References}

[1] Information NC for B, Pike USNL of M 8600 R, MD B, Usa 20894: Extragonadal germ cell tumors treatment (PDQ $\left.{ }^{\circledR}\right)$. PubMed Health [Internet]. 2015 Feb 25 [cited 2015 Mar 28]; Available from: http://www.ncbi.nlm.nih.gov/books/PMH0032582/ 
[2] Dueland S, Stenwig AE, Heilo A, et al. Treatment and outcome of patients with extragonadal germ cell tumours-the Norwegian Radium Hospital's experience 1979-94. Br J Cancer. 1998; 77(2): 329-35. PMid:9461006 http://dx.doi.org/10.1038/bjc.1998.51

[3] Womeldorph CM, Zalupski MM, Knoepp SM, et al. Retroperitoneal germ cell tumor diagnosed by endoscopic ultrasound-guided fine needle aspiration. World J Gastrointest Oncol. 2010; 2(12): 443-5. PMid:21191538 http://dx.doi.org/10.4251/wjgo.v2.i12.443

[4] Albany C, Einhorn LH. Extragonadal germ cell tumors: clinical presentation and management. Curr Opin Oncol. 2013; 25(3): 261-5. http://dx.doi.org/10.1097/cco.0b013e32835f085d

[5] Scholz M, Zehender M, Thalmann GN, et al. Extragonadal retroperitoneal germ cell tumor: evidence of origin in the testis. Ann Oncol. 2002; 13(1): 121-4. PMid:11863093 http://dx.doi.org/10.1093/annonc/mdf003

[6] Wang L, Pitman MB, Fernandez-del Castillo, et al. Choriocarcinoma involving the pancreas as first manifestation of a metastatic regressing mixed testicular germ cell tumor. Mod Pathol. 2004; 17: 1573-80. PMid:15545958 http://dx.doi.org/10.1038/modpathol.3800226

[7] Schmidt OA, Stahl U, Brueck M. Posthepatic obstructive jaundice caused by primary extragonadal germ-cell tumor in a patient with glucose-6-phosphate dehydrogenase deficiency. Dtsch Med Wochenschr. 2010; 135: 2181-5. PMid:20979002 http://dx.doi.org/10.1055/s-0030-1267496

[8] Wang J, Zheng Z, Qiu Y, et al. Primary mixed germ cell tumor arising in the pancreatic head. J Pediatric Surg. 2013 ; 48 : E21-24. PMid:23331834 http://dx.doi.org/10.1016/j.jpedsurg.2012.10.054

[9] Wang F, Liu A, Peng Y, et al. Diagnostic utility of SALL4 in extragonadal yolk sac tumors: an immunohistochemical study of 59 cases with comparison to placental-like alkaline phosphatase, alpha-fetoprotein, and glypican-3. Am J Surg Pathol. 2009; 33(10): 1529-39. PMid:19574883 http://dx.doi.org/10.1097/PAS.0b013e3181ad25d5

[10] Benali HA, Lalya L, Allaoui M, et al. Extragonadal mixed germ cell tumor of the right arm: description of the first case in the literature. World Journal of Surgical Oncology. 2012; 10(1):69.

[11] International Germ Cell Consensus Classification: a prognostic factor-based staging system for metastatic germ cell cancers: International Germ Cell Cancer Collaborative Group. J Clin Oncol. 1997; 15(2): 594-603. PMid:9053482

[12] Hartmann JT, Nichols CR, Droz J-P, et al. Hematologic disorders associated with primary mediastinal nonseminomatous germ cell tumors. JNCI J Natl Cancer Inst. 2000; 92(1): 54-61. http://dx.doi.org/10.1093/jnci/92.1.54

[13] Alanee SR, Feldman DR, Russo P, et al. Long-term mortality in patients with germ cell tumors: Effect of primary cancer site on cause of death. Urologic Oncology: Seminars and Original Investigations. 2014; 32(1): 26.e9-26.e15. PMid:23410944 http://dx.doi.org/10.1016/j.urolonc.2012.09.003

[14] Ulbright TM. Germ cell tumors of the gonads: a selective review emphasizing problems in differential diagnosis, newly appreciated, and controversial issues. Mod Pathol. 2005; 18(S2): S61-79. PMid:15761467 http://dx.doi.org/10.1038/modpathol.3800310

[15] Saxman SB, Nichols CR, Einhorn LH. Salvage chemotherapy in patients with extragonadal nonseminomatous germ cell tumors: the Indiana University experience. J Clin Oncol. 1994; 12(7): 1390-3. PMid:8021729

[16] Weissferdt A, Rodriguez-Canales J, Liu H, et al. Primary mediastinal seminomas: a comprehensive immunohistochemical study with a focus on novel markers. Human Pathology. 2015; 46(3): 376-83.

[17] Yetisyigit T, Babacan N, Urun Y, et al. Predictors of outcome in patients with advanced nonseminomatous germ cell testicular tumors. Asian Pac J Cancer Prev. 2014; 15(2): 831-5. PMid:24568504 http://dx.doi.org/10.7314/APJCP.2014.15.2.831

[18] Wang SK, Zynger DL, Hes O, et al. Discovery and diagnostic value of a novel oncofetal protein: Glypican 3. Advances In Anatomic Pathology. 2014; 21(6): 450-60. PMid:25299314 http://dx.doi.org/10.1097/PAP.0000000000000043

[19] Liu A, Cheng L, Du J, et al. Diagnostic Utility of novel stem cell markers SALL4, OCT4, NANOG, SOX2, UTF1, and TCL1 in primary mediastinal germ cell tumors. The American Journal of Surgical Pathology. 2010; 34(5): 697-706. PMid:20410807 http://dx.doi.org/10.1097/PAS.0b013e3181db84aa 